\title{
The Shift from Traditional Marketing to Entrepreneurial Marketing Practices: A Literature Review
}

\author{
Abdul Rahim, $\mathrm{H}^{1}$, Ab. Wahab, $\mathrm{K}^{1}$, Saad, $\mathrm{A}^{2}$ \\ ${ }^{1}$ Islamic Science University of Malaysia, Malaysia \\ ${ }^{2}$ INTI International University, Nilai, Malaysia \\ Correspondence: Abdul Rahim, H, Islamic Science University of Malaysia, Malaysia
}

Received: February 15, 2015 Accepted: February 27, 2015 Online Published: July 30, 2015

doi:10.11114/bms.v1i2.993

URL: http://dx.doi.org/10.11114/bms.v1i2.993

\begin{abstract}
Small and medium enterprise(SME) have always been an interesting subject for research. In comparison to larger business organizations, SMEs faced many challenges including how they manage daily marketing activities and make marketing related decision. This study compiles the related literature review on the issues of traditional marketing and entrepreneurial marketing.

Purpose: This study aims to explore the role of marketing practices in small and medium sized enterprises (SMEs) and to evaluate the impact of changes in marketing practices from traditional to entrepreneurial marketing practices will have an impact on the SME performance.

Research methodology: A compilation of related literature review on traditional marketing and entrepreneurial marketing was done. An observation on the changes in marketing practices in small and medium enterprises towards a more innovative marketing practice were identified.

Findings: Marketing in SMEs is centered on traditional methods such as using print media and hard selling. SME owners should take account of the findings and work towards introducing SME-specific marketing practices in trying to achieve higher sales volume and growth. In the study area which is Klang Valley, Malaysia the shift from traditional marketing to entrepreneurial marketing was observed amongst the SMEs being studied.

Research limitations: This study uses a small number of SME companies in one region and therefore the generalizability of the findings may be limited. Further research could extend the number of SME companies and to other regions of Malaysia.

Practical Implications: The findings have a bearing on the Malaysian SME performance. This study offers insights into how the marketing practices in Malaysian SMEs needs to be adapted in light of the findings to ensure marketing practices of SMEs are compatible with current digital approaches.
\end{abstract}

Keywords: small and medium sized enterprises (SME), marketing practices and capabilities, traditional marketing, entrepreneurial marketing

\section{Introduction}

Although research on small and medium sized enterprise (SME) marketing has increased in recent years, existing findings have not been reflected in the marketing practices amongst SMEs in Malaysia. Large organizational models applied to small firms setting have been criticized in the literature (Gilmore et al, 2001) and there is a need for further research to identify how marketing is practiced within the small and medium sector (Blankston \& Stokes, 2002). This study aims explore how SME owners practice marketing ad provide solution that are cogsinant of the realities of small business ownership which has witnessed drastic changes with the usage of more digital and virtual medium.

The strategic marketing literature first began to deal with SMEs 20 years ago (Carson and Gilmore, 2000; Gilmore et al, 2001; Julien \& Ramangalahy, 2003) and some topics like SMEs' market orientation, international growth and strategic operations have received extensive attention (Juilen \& Ramangalahy, 2003; Kara et al, 2005; Blankston et al, 2006; Paccito et al, 2007). However, there is some evidence that the role and relevance of marketing in SMEs depends on certain differences in marketing activities and on the organization for marketing within these companies (Simpson et al, 
2006). There is still insufficient knowledge about marketing in small business and in particular, in relation to the understanding of strategic marketing practices (Siu \& Kirby, 1998).

\subsection{Definitions of Entrepreneurial Marketing (EM)}

A more radical definition of EM is that it considers that EM is a total integration of marketing and entrepreneurship "the construct of EM is not simply the nexus between the sets of marketing and entrepreneurial processes that has emerged as the conventional conceptualisation of EM ... but fully includes all aspects of AM (administrative marketing) and entrepreneurship" (Morrish, Miles et al., 2010, p. 305) and thus it becomes a strategic orientation, exceeding the marketing function (Schindehutte \& Morris, 2010).

Instead, the other definitions consider EM as an alternative perspective to traditional marketing and associates it with innovative marketing techniques "this term (EM) is used as an integrative conceptualization that reflects such alternative perspectives as guerilla marketing, radical marketing, expeditionary marketing, disruptive marketing and others." (Morris, Schindehutte et al., 2002, p. 1).

The other type of EM definitions has a different perspective and is based on company lifecycle. Kotler (2003, pp. 4-5) believes that in its early stages that when the company is small, flexible and willing to experience new things as an informal type of marketing is practiced and this would be EM defined as "Most companies are started by individuals who live by their wits. They visualize an opportunity and knock on every door to gain attention". As the company grows and matures, marketing practices are more rigorous, planning is essential and the company reaches the second stage, called formalized marketing: "As small companies achieve success, they inevitably move toward more formulated marketing". The third phase is when the formalized approach becomes excessive and therefore a change is needed, a different type of marketing called Intrapreneurial Marketing (IM) which can be a subject for further research.

\subsection{Traditional Marketing Practices and Entrepreneurial Marketing Practices}

Entrepreneurial marketing cannot exist in the absence of the entrepreneur. Unlike traditional marketing, which is exclusively customer-centric focused, in entrepreneurial marketing the customer and the entrepreneur are equally important actors that shape the culture, strategy and firm behaviour. EM is influenced by entrepreneur's personal characteristics and values. But there is no consensus about the relationship between factors related to personal traits which consists of experience, education level, propensity to risk, preference for innovation, tolerance for ambiguity. Meanwhile for firm performance, the results shown are contradictory (Andersson \& Tell, 2009).

A consensus emerged regarding how entrepreneurs think and make decisions with consequences on marketing practice. There are five significant differences between the way non-entrepreneurs think which is predictive logic and how entrepreneurs think which is effectual logic (Dew, R. et al., 2009):

1) Vision for future. It is predictive for predictive logic and creative for effectual logic. In the first case, the future is seen as a causal continuation of the past and therefore can be predicted. In the second case the future is shaped, at least partially, by voluntary actions of agents and therefore his prediction is not possible;

2) Basis for making decisions. In predictive logic, actions are determined by purposes. In effectual logic, actions are determined by available means. Purposes "are born" by imagining courses of action based on those available means;

3) Attitude toward risk. In predictive logic, an option is selected based on maximum gain while in effectual logic an option is chosen based on how much the entrepreneur can afford to lose by selecting it;

4) Attitude toward outsiders. Competition as in the case of predictive logic and cooperation - in case of effectual logic;

5) Attitude towards unexpected contingencies: avoidance as in case of predictive logic and fructification as in the effectual logic. Accurate predictions, careful planning and focus on objectives which are specific to predictive logic and making contingencies to be perceived as obstacles to be avoided. Avoiding predictions, imaginative thinking, continuous transformation of objectives, which are specific to effectual logic and making contingencies to be perceived as opportunities to create something new and therefore are appreciated.

Marketing theories are typically taught from conventional textbooks (for example, Brassington \& Pettitt, 2007; Jobber, 2009; Kotler et al, 2008) which focus on marketing activities such as planning, marketing research and the implementation of the marketing mix (4Ps and 7Ps). These theories are designed for large organization, where financial resources and marketing expertise are more readily available. Owing to the unique characteristics and constraints of SMEs, including the inherent characteristics of SME owners and managers, the dynamic business environment and the lack of resources within SMEs (for example Chaston, 1997; Gilmore et al, 2001; Hill \& Wright, 2001; O’Dwyer et al, 2009 ) it is inappropriate to assume SMEs can adopt the same or similar marketing approaches as large organization (Hill, 2001). Hence, there is a need to develop and refine existing marketing models, which can be used to profile the marketing practices in small firm (Moriarty et al, 2008). 
To date, marketing theories and concepts have been based around large organizational practice and it could be argued that conventional marketing definitions, theories and models in textbooks may not apply to the context of small firms (Carson, 2003; McCartan-Quinn \& Carson, 2003; Moriarty et al., 2008; Simpson et al, 2006; Stokes \& Wilson, 2010). It is believed that marketing is practiced by small firms, although the degree of activities varies according to the nature of the industry (Simpson et al., 2006). Blankston et al. (2006) pointed out in their research that small firms do not practice textbook marketing because of their distinct marketing style. Gilmore et al. (2001) \& Hill \& McGowan (1999) also state that the marketing characteristics of SMEs are different from the conventional ones of marketing textbooks \& that the need to conduct research, which is adapted to the unique characteristics of small firms is apparent (Hill, 2001).

It could be argued that the SMEs pay less attention to marketing as an important function of the business because marketing is often perceived as a large organization activity (Stokes \& Blackburn, 1999) and moreover, marketing is seen as a "troublesome and problematic undertaking for SMEs" (Krake, 2005). Existing literature highlights that the characteristics of SME marketing are different from those of large organizations in ways that it takes into account the firm's unique business environment, characteristics of owners and managers such as skills and abilities and resources (O'Dwyer et al, 2009). Management culture is more innovative and entrepreneurial in a small firms setting and SME owners and managers tend to be more proactive and opportunistic in nature (Day et al, 1998). Numerous authors agree that SME marketing practices and decision making tends to be more creative, alternative, instinctive (O'Dwyer et al, 2009), informal and unstructured (Gilmore et al, 2001), chaotic and unplanned (Carson et al., 1998; Hill \& Wright, 2001).

An increasing number of studies have taken into account SME owners and managers features into considerations when applying marketing theories to the small business context (O'Dwyer, 2009. In the study of Hill and McGowan (1999) on marketing planning, it has been asserted that the conventional marketing planning theories and concepts do not conform to the small firms setting due to the unique personality and managerial competencies of owners and managers. A holistic model of marketing has also been developed by Hill (2001) who emphasizes the core competencies of SMEs such as the complexity of the SME business environment and characteristics of SMEs owners and managers. This model integrates and highlights the activities and characteristics of SMEs, including sales orientation, use of personal contact network and decision making style (Hill, 2001). The differences between how marketing is practiced between small firms and large organizations are apparent, especially in setting and achieving long-term objectives and carrying out market research (Blankston \& Stokes, 2002).

Marketing is not only a functional area in large corporations; it applies to SMEs or new ventures as well. Entrepreneurial behaviour has traditionally been linked to the SME sector. Though, in these kinds of enterprises, often being faced by limited financial and human resources, marketing is different to the standard marketing textbook approaches (for example Kotler, 1994) being originally developed for larger enterprises and widely ignoring the marketing particularities of SMEs (Kraus et al., 2007; Grünhagen \& Mishra, 2008). Marketing is one business function which needs to be used appropriately by the entrepreneur for successfully leading his venture (Richard et. al, 2012; Helmers, 2009; Hisrich, 1992).

The intersection between entrepreneurship and marketing becomes evident. Successful entrepreneurs practice marketing and the better marketers are entrepreneurial (Day et al., 1998). Several entrepreneurial activities, for example the identification of new opportunities, the application of innovative techniques, the conveyance of the products to the marketplace, or the successful meeting of customer needs, are also fundamental aspects of marketing theory (Collinson and Shaw, 2001).

By summarising several empirical studies on that topic, Hills \& Hultman (2006) discovered several specific characteristics of EM, such as:

1) Entrepreneur or the owner-manager being central to marketing.

2) Decisions being linked to personal goals and long-time performance.

3) The exploitation of smaller market niches with a customized range of products and services.

4) Marginal market power.

5) Marketing penetrating all levels and functional areas of the firm.

6) Marketing based on personal reputation, trust and credibility.

7) Heavy focus on sales and promotion.

8) Lack of formal planning and strategy, reliance on intuition and experience of owner, individual-related value creation.

9) Smallness and lack of marketing resources, no division of marketing work. 
10) Formal market research is rare, rather making use of personal contacts and networks.

11) Interactive and innovative product or venture development.

12) Inherent focus on opportunity recognition, proactiveness and calculated risk.

13) 13) Flexibility and fast reactions to customer preference shifts.

14) 14) Inherent risk of market exit.

15) 15) A role for passion, enthusiasm and commitment, as well as for leading instead of following customers.

For entrepreneurs and owner managers of small enterprise, marketing is a method or in other words, a tactic for catching opportunities. They don't consider marketing as an organizational culture or a strategic process, rather their definition of marketing have been taken from their own subject and have great emphasis on using promotion techniques to attract customers while ignore other non-promotional aspects of marketing such as product development, pricing and distribution strategy. Most of the owner managers of small enterprise believe that their business relies on word of mouth marketing so they have no need to use informal marketing techniques. This does not necessarily mean that they do not have peers on fundamental aspects of marketing, but in fact they are not familiar with the concepts and terminology in this area and their assumption comes from their personal experiences (Stokes, 2000).

Entrepreneurial marketing is developed by the individual person, who will adapt traditional marketing frameworks to suit the specific situation of the firm. They will have a product or service to offer to the market place, at a price and they will promote and deliver this using an affordable method and medium. This will be done in a pragmatic and practical way that suits the firm and will be structured around the existing functions and activities of the firm itself (Gilmore \& Carson, 2007).

Companies with small budgets such as start-ups and SMEs have little to spend on promotion. Therefore, they need to promote their business by word of mouth and other below the line activity. They often build business based on the positive nature of staff and customer interactions and relationships. They may also obtain products and offer services outside their normal remit and provide a customized version of their standard offering to key customers to ensure that they stay loyal to their company rather than looking elsewhere for accessories, for example. In this way, entrepreneurs will need to take an integrative approach to sell their whole range of products and services.

\section{Theoretical Framework.}

$$
\begin{array}{|c|c|c|}
\begin{array}{c}
\text { Traditional Marketing } \\
\text { Practices }
\end{array} & \multicolumn{1}{c}{\begin{array}{c}
\text { Entrepreneurial } \\
\text { Marketing Practices }
\end{array}} \\
\hline
\end{array}
$$

The proposed theoretical framework for the research is as above. It is observed whether there are shifts from the traditional marketing practices to entrepreneurial marketing practices amongst the subject matter.

Table 1. Theoretical and empirical evidence on Entrepreneurial Marketing

\begin{tabular}{lll}
\hline $\begin{array}{l}\text { Conceptual } \\
\text { Background }\end{array}$ & Theoretical rationals (author, year) & Empirical Evidence (author, year) \\
\hline Entrepreneurship & $\begin{array}{l}\text { Dat et.al (1998), Knight (2000), Fillis (2004), } \\
\text { Li et. al (2006), Webb et. al (2011) }\end{array}$ & $\begin{array}{l}\text { Morris et. al (1998). Davis et. al (1998), } \\
\text { Sarkar et. al (2001), Fillis (2004), Li et. al (2006), } \\
\text { Nasution et. al (2011), Thukral et. al (2008), } \\
\text { Clausen \& Korneliussen (2012) } \\
\text { Schindehutte et. al (2008) }\end{array}$ \\
Marketing & $\begin{array}{l}\text { Styles \& Seymour (2006), Schindehutte } \\
\text { et. al (2008), Miles \& Darroch (2008) }\end{array}$ & $\begin{array}{l}\text { Morris \& Paul (1987), Atuahene-Gima \& Ko } \\
\text { (2001), Bhuian et. al (2005), Miles \& Darroch } \\
\text { Entrepreneurial }\end{array}$ \\
$\begin{array}{l}\text { Hills et. al (2008), Hoy (2008), Jones \& } \\
\text { Rowley (2011) }\end{array}$ & $\begin{array}{l}\text { 2005) Gonzalez-Benito et. al (2011), Chen } \\
\text { et. al (2012), Boso et. al (2012), Mort et. al (2012) }\end{array}$ \\
\hline
\end{tabular}

Source: Hills et. al (2011) 
Table 2.The evolution of Entrepreneuship definitions

\begin{tabular}{|c|c|c|c|}
\hline Year & Scholar & Characteristics of entrepreneurial & Core characteristic \\
\hline 1775 & Cantilion & $\begin{array}{l}\text { 1)entrepreneur as a dealer-agent } \\
\text { 2)entrepreneur do not see any difference } \\
\text { between risk and uncertainty } \\
\text { 3)emphasis on interaction of } \\
\text { entreprenuerial goals }\end{array}$ & $\begin{array}{l}\text { power trading in risk (for } \\
\text { Factor of production) }\end{array}$ \\
\hline 1800 & Say & $\begin{array}{l}\text { 1) A main input in the production process } \\
\text { 2) With management and judgement } \\
\text { Power } \\
\text { 3) Use his/her judgement power to } \\
\text { recognize opportunity }\end{array}$ & Judgement power \\
\hline 1875 & Marshal & $\begin{array}{l}\text { 1) Emphasis on innovation in addition to } \\
\text { emphasis on two previous view } \\
\text { 2) Innovation to reduce costs }\end{array}$ & Innovation \\
\hline 1911 & Schumpeter & $\begin{array}{l}\text { 1) innovator and creator of new } \\
\text { component } \\
\text { 2) will tolerate uncertainty } \\
\text { 3) Banker }\end{array}$ & $\begin{array}{l}\text { Innovation and creation } \\
\text { new component }\end{array}$ \\
\hline 1921 & Knith & $\begin{array}{l}\text { 1) Distinguish risk and uncertainty } \\
\text { 2) will tolerate uncertainty }\end{array}$ & Uncertainty taker \\
\hline 1973 & Kerzner & $\begin{array}{l}\text { 1) Have entrepreneurial conciseness } \\
\text { 2) Have access to information } \\
\text { 3) Recognize opportnuity witj usage of } \\
\text { information } \\
\text { 4) Make imbalance in market }\end{array}$ & Entrepreneurial Conciseness \\
\hline 1975 & Shultz & $\begin{array}{l}\text { 1) Coordination and resource allocator } \\
\text { 2) Entrepreneur as interactive }\end{array}$ & Resource allocator \\
\hline 2000 & $\begin{array}{c}\text { Shane and } \\
\text { Venkateraman }\end{array}$ & 1) Entrepreneur as Nexus Opportunity & Nexus with opportunity \\
\hline 2003 & Cason & Decision maker & Decision making \\
\hline
\end{tabular}

\section{Discussion and Conclusion.}

Existing literature suggests that the characteristics of SME marketing are definitely different from those of large organizations. SME marketing takes into account the unique business environment, characteristics of owner and managers, such as skills, abilities and business environment and resources (O'Dwyer et al, 2009). The findings from this study support this notion and also suggest that the level of commitment to marketing varies by business context, by level of marketing expertise and by the maturity of the company.

Marketing was identified by the SMEs as engagement with customers, matching customer needs, word of mouth communication and networking and these findings support existing literature (Day et al, 1998; Gilmore et al, 2001). In addition, the study revealed that within certain small business environments, traditional marketing activities such as advertising and sales promotion of services were perceived to be damaging to credibility with owners preferring to craft their activities to suit their individual business dynamics. Marketing was also regarded as a separate activity within the business and one that that could be accessed as necessary or as an opportunist basis rather than as an intrinsic part of the whole business function and the findings suggest that marketing within an SME context can be unskilled activity that requires little time or training and which anyone in the company can undertake.

It is therefore not surprising that according to Simpson and Taylor (2001) many SME owners perceived sales and marketing as the most dominant problem they encounter when running their business. Our findings add to this by suggesting that SMEs deal with their lack of marketing expertise through concentration on other activities such as networking and customer engagement although, arguable this is not a lack of marketing expertise but rather a redefining of the parameters of marketing.

\section{Acknowledgement}

I would like to thank all the individuals involved in producing this paper. Thank you to all involved and for the assistance I received financially during this process.

\section{References}

Arens \& Weigold (2011). Contemporary Advertising Textbook, Mc-Graw Hill International Edition, Thirteenth Edition Armstrong \& Kotler (2013). Marketing: An Introduction Textbook, Pearson Publishing, Eleventh Edition.

Carson, D., \& Gilmore, A. (2000). Marketing at the interface: not 'what' but 'how'. Journal of Marketing Theory and 
Practice, 8(2), 1-7.

Davidson, P., \& Honing, B. (2003). The role of social and human capital among nascent entrepreneurs. Journal of Business Venturing, 20,121. http://dx.doi.org/10.1016/s0883-9026(02)00097-6

Drucker, P. F. (1994). Innovation and Entrepreneurship : Practice and Principles, Heinemann, London

Gilmore, A. (2011). Entrepreneurial and SME Marketing. Journal Of Research in Marketing and Entrepreneurship. 13, 137-145. http://dx.doi.org/10.1108/14715201111176426

Gilmore, A., \& Carson, D. (2009). Innovative marketing in SMEs: an empirical study. Journal of Strategic Marketing, 17(5), 383-396. http://dx.doi.org/10.1080/09652540903216221

Hill, J. (2001a). A multidimensional study of the key determinants of effective SME marketing activity: Part 1. International Journal of Entrepreneurial Behaviour \& Research, 7(5), 171-204. http://dx.doi.org/10.1108/EUM0000000006006

Hill, J. (2001b). A multidimensional study of the key determinants of effective SME marketing activity: Part 2. International Journal of Entrepreneurial Behaviour \& Research, 7(6), 211-235. http://dx.doi.org/10.1108/EUM0000000006538

Martin, D. (2009). An Entrepreneurial marketing mix. Qualitative Market Research. An International Journal, 12, 391-403. http://dx.doi.org/10.1108/13522750910993310

Michele, O’D. (2009). Marketing the SME: Innovation and Approach, Cambridge Scholars Publishing. British Library Cataloguing in Publication Data.

Morrish, S. (2008). 42Below: exploring vodka opportunities. Walker, O.C., Gountas, J., Mavondo, F., Mullins, J.W., Boyd, H. W., \& Larre'che', J. C. (Eds), Marketing Strategy and Cases: A Decision-focused Approach, 1st ed., McGraw-Hill, Sydney, 370-375.

O’Dwyer, M., Gilmore, A., \& Carson, D. (at press), Innovative Marketing in SMEs: An empirical study, Journal of Strategic Marketing

Stokes, D. (2000). Putting entrepreneurship into marketing: The processes of entrepreneurial marketing. Journal of Research in Marketing and Entrepreneurship, 2(1), 1-6. http://dx.doi.org/10.1108/14715200080001536

Sussie, C. M. (2011). Entrepreneurial marketing: a strategy for the twenty-first century? Journal of Research in Marketing and Entrepreneurship, 13(2), 110-119. http://dx.doi.org/10.1108/14715201111176390

\section{(cc) $\mathrm{BY}$}

This work is licensed under a Creative Commons Attribution 3.0 License. 